\title{
In vitro Effect of Culture Filtrates of Chaetomium Globosum on Growth of Soil Borne Pathogens
}

\author{
K. W. Uikey ${ }^{1^{*}}$, K. S. Raghuwanshi and D. W. Uikey \\ Department of Plant Pathology and Agricultural Microbiology, \\ PGI, M.P.K.V., Rahuri, Maharashtra, India-413722 \\ *Corresponding author
}

A B S T R A C T

Ke y w o r d s
Antagonism,
Pathogen,
Biocontrol agent,
Efficacy
Article Info
$\begin{aligned} & \text { Accepted: } \\ & 23 \text { April } 2020 \\ & \text { Available Online: } \\ & \text { 10 May } 2020\end{aligned}$

Keywords

Antagonism,

Pathogen,

Biocontrol agent, Efficacy

Accepted:

23 April 2020

10 May 2020
In in vitro evaluation of cultural extract of Chaetomium globosum against Fusarium, Sclerotium and Rhizoctonia, it was observed that inhibition of pathogen was increased with increase in concentration of metabolite indicating the antifungal properties against pathogen. Chaetomium globosum showed maximum antagonistic effect to Fusarium $(51.50 \%)$ at $100 \%$ concentration. Significantly minimum inhibition zone $(20 \%)$ was observed at $25 \%$ for Fusarium spp. Effect of culture filtrate did not show any inhibition effect against soil borne pathogens Sclerotium and Rhizoctonia.

\section{Introduction}

Biological control of plant pathogens is currently accepted as a key practice in sustainable agriculture because it is based on the management of natural resources, i.e. certain rhizosphere organisms, common components of ecosystems, known to develope antagonistic activities against harmful organisms. Soil borne disease organisms are widely found in soil. As a group, they can affect a wide range of plants, including fruits and vegetables, ornamental plants, trees, and shrubs. Common names for plant disease often reflect the visual damage to the plant but do not necessarily indicate the pathogen responsible for the disease.

For example, seedling damping-off, the condition when seedlings die or fall over can occur in most vegetables and can be caused by Pythium, Phytophthora, Rhizoctonia, Fusarium, Sclerotium, or any combination of these. Identification of symptoms of root 
diseases include wilting, dieback, browning or rotting of tissues, and cankering. Chaetomium is a genus belonging to the class Pyrenomycetes (Ascomycotina), order Sordariales and family Chaetomiaceae. It is a dematiaceous (dark-walled) mold normally found in soil, air, and plant debris.

There are about 95 species in the widespread genus (Kirk et al., 2008). Members of this genus typically have superficial, ostiolar perithecia, covered in hairs. Asci are often clavate and evanescent, bearing eight spores.

Chaetomium globosum strains are saprobic organisms and their ability to suppress plant pathogens resulted to induced growth, and high yield of the plant (Sibounnayong et al., 2005). Chaetomium species can be found in leguminous plants like peanuts and mungbean and also on graminous plants like rice.

A gene of Chaetomium globosum, 46-kDa codes for an endokinase (chi46) that degrades cell walls of plant pathogens Rhizoctonia solani, Fusarium oxysporum, Sclerotinia sclerotiorum, Valsa sordida, S. tritici and Phytophthora sojae (Liu et al., 2008).

Growers need to know which treatments are most effective for their specific problems and growing conditions in order to prevent needless expenses, ineffective treatments, and crop losses. In 2009, soil borne pathogens were responsible for an estimated $10 \%$ of losses in vegetable crops.

Because fungicide use is not consistently effective, economical, ecologically desirable (due to environmental and worker exposure concerns), or commercially desirable while production of pesticide-free or organic crops can increase crop value by $30 \%$, biological control and plant growth promoting agents should be considered key management components (Anonymous 2012).

\section{Materials and Methods}

\section{Effect of culture filtrates / metabolites of Chaetomium globosum on growth of soil borne pathogens by filter paper disc method}

The effect of culture filtrates of Chaetomium globosum was studied under in vitro conditions. The basic view was to evaluate the metabolites of Chaetomium for the control of soil borne pathogens. The fresh culture of Chaetomium was prepared and inoculated in $100 \mathrm{ml}$ PD broth. These inoculated broth containing conical flasks were incubated for 15 days at room temperature.

After 15 days of incubation the culture extracts were filtered through G4 filter paper. Then these extracts were stored in sterile conical flask for further use. Antifungal activity of the culture extracts was evaluated using paper disc method. Half litre of PDA medium was prepared in one litre Borocil flask, and equally distributed in five $100 \mathrm{ml}$ capacity flask and autoclaved. Further it was allow to cool to $48-50^{\circ} \mathrm{C}$ and fungus suspension of Fusarium, Sclerotium and Rhizoctonia respectively were added to each flask containing warm media and was quickly poured into petriplates and allowed to solidify.

Paper discs of $5 \mathrm{~mm}$ diameter cut from G4 filter paper get sterilized and loaded with aqueous extract of metabolite. The loaded discs were kept onto the surface of the petriplates containing fungus seeded PDA medium. Paper disc without metabolite served as check. Each treatment was replicated seven times. The plates were incubated at $28 \pm 2^{0} \mathrm{C}$ for $48 \mathrm{hrs}$. The inhibition zone/lysis of fungus pathogen around the paper disc was measured with a millimetre scale. Accordingly, culture extract or metabolites of isolates were evaluated. 


\section{Results and Discussion}

Data pertaining to sensitivity of Fusarium, Sclerotium and Rhizoctonia to culture extracts of Chaetomium globosum at various concentration viz., 25\%, 50\%, $75 \%$ and $100 \%$ are presented in Table 1 and Plate no. 1 which revealed that inhibition of growth of pathogen was significantly different due to different concentration of metabolites/culture extracts. Out of three test pathogens viz, Fusarium,
Sclerotium and Rhizoctonia, Fusarium showed maximum inhibition zone $(51.50 \%)$ at $100 \%$ concentration of Chaetomium culture extracts. Significantly minimum inhibition zone $(20 \%)$ was observed at $25 \%$ for Fusarium spp. only. The inhibition of Fusarium was increased with increase in concentrations of culture filtrate. Effect of culture filtrate did not show any inhibition effect against soil borne pathogens Sclerotium and Rhizoctonia (Fig. 1).

Table.1 Effect of culture filtrate/metabolites on growth of soil borne pathogens

\begin{tabular}{|c|c|c|c|c|c|c|c|}
\hline \multirow{3}{*}{$\begin{array}{l}\text { Sr. } \\
\text { No }\end{array}$} & \multirow[t]{3}{*}{ Treatment } & \multicolumn{6}{|c|}{ Effect of culture filtrate of Chaetomium } \\
\hline & & \multicolumn{2}{|c|}{ Fusarium } & \multicolumn{2}{|c|}{ Sclerotium } & \multicolumn{2}{|c|}{ Rhizoctonia } \\
\hline & & $\begin{array}{c}\text { Mean } \\
\text { Growth } \\
(\mathrm{mm})\end{array}$ & $\begin{array}{c}\text { Inhibition } \\
\%\end{array}$ & $\begin{array}{l}\text { Mean } \\
\text { Growth } \\
(\mathrm{mm})\end{array}$ & $\begin{array}{c}\text { Inhibition } \\
\%\end{array}$ & $\begin{array}{c}\text { Mean } \\
\text { Growth } \\
(\mathrm{mm})\end{array}$ & $\begin{array}{c}\text { Inhibition } \\
\%\end{array}$ \\
\hline 1 & Chaetomium $25 \%$ & 72 & 20 & 90 & 00 & 90 & 00 \\
\hline 2 & Chaetomium $50 \%$ & 65 & 27 & 90 & 00 & 90 & 00 \\
\hline 3 & $\begin{array}{c}\text { Chaetomium } \\
75 \%\end{array}$ & 51.3 & 43 & 90 & 00 & 90 & 00 \\
\hline 4 & $\begin{array}{c}\text { Chaetomium } \\
100 \%\end{array}$ & 43.6 & 51.5 & 90 & 00 & 90 & 00 \\
\hline 5 & Control & 90 & 00 & 90 & 00 & 90 & 00 \\
\hline 7 & $\mathrm{SE}( \pm)$ & 1.34 & 00 & 00 & 00 & 00 & 00 \\
\hline 8 & CD@5\% & \multicolumn{2}{|c|}{3.69} & \multicolumn{2}{|r|}{ NS } & \multicolumn{2}{|r|}{ NS } \\
\hline
\end{tabular}

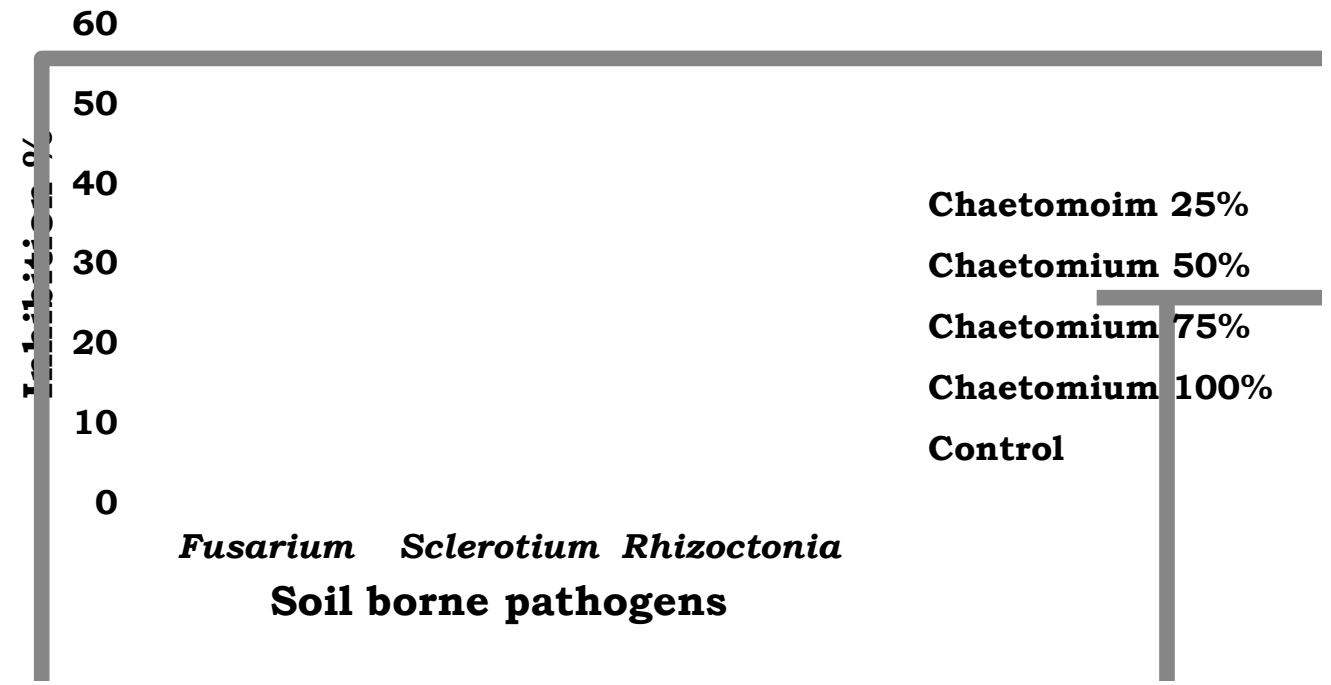

Fig.1 Effect of culture filtrates /metabolites of Chaetomium on growth of soil borne pathogens 


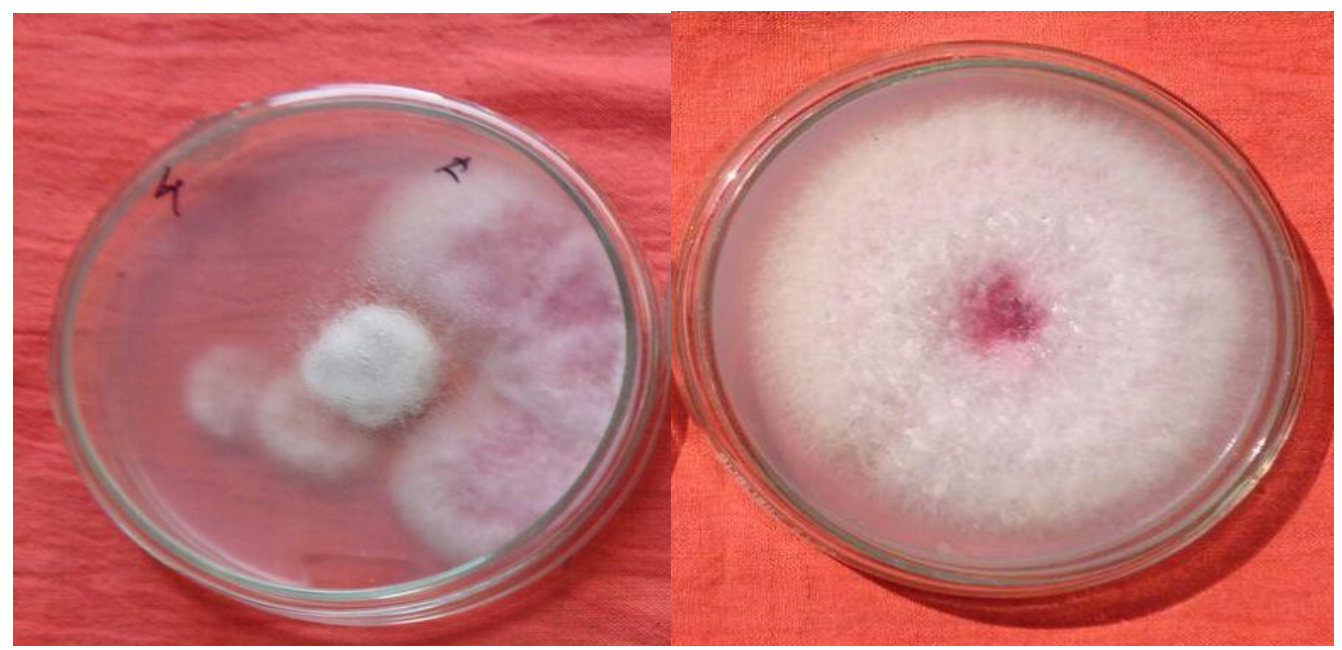

Treatment

Control

Plate.1a Effect of culture filtrates/ metabolites of Chaetomium on growth of Fusarium spp.

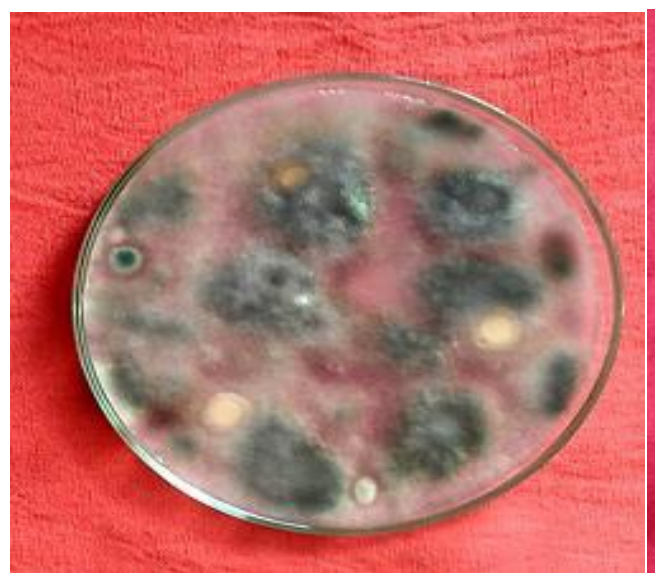

Treatment

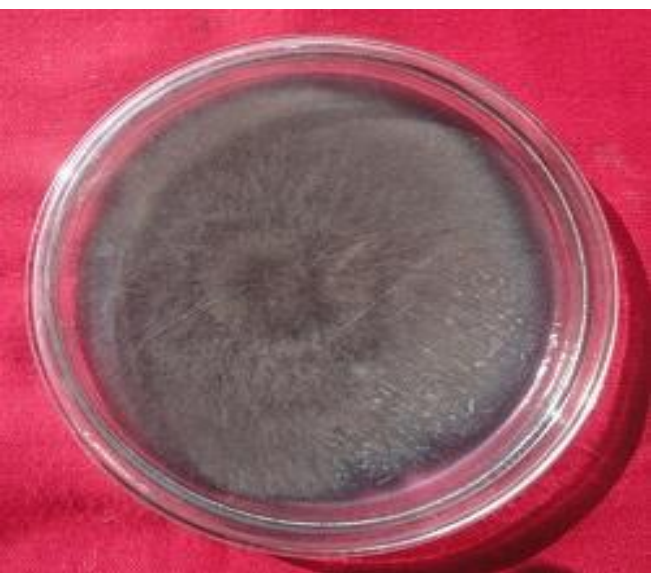

Control

Plate.1b Effect of culture filtrates/ metabolites of Chaetomium on growth of Rhizoctonia spp.

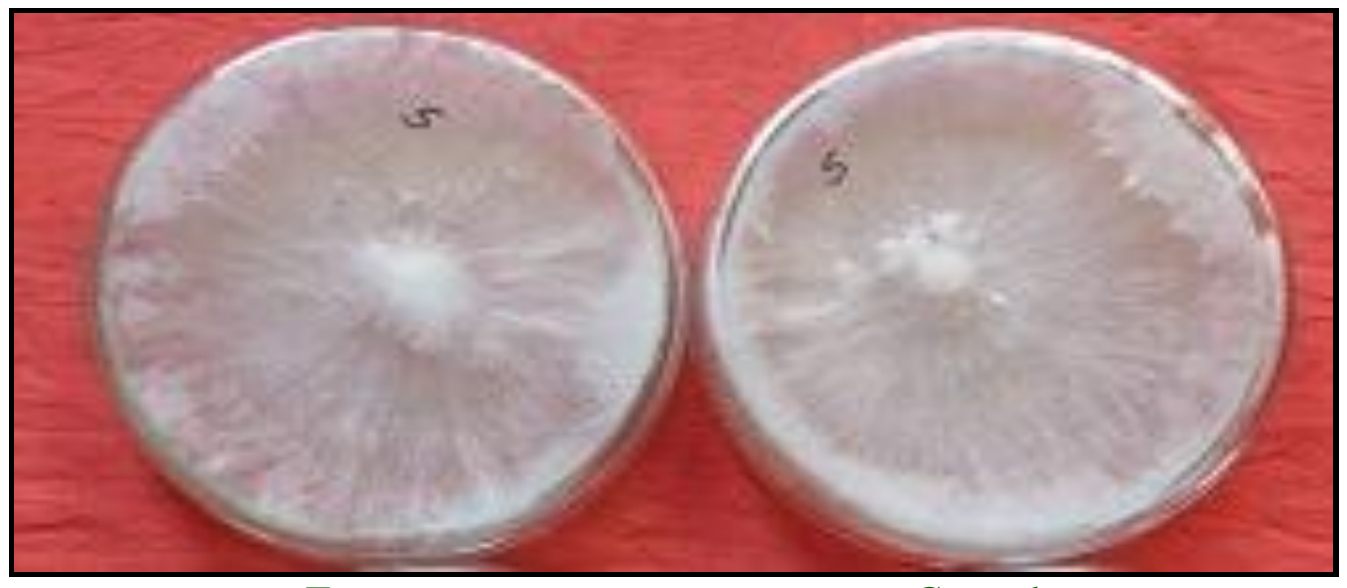

Treatment

Control

Plate.1c Effect of culture filtrates/metabolites on growth of Sclerotium spp.

Plate.1 In vitro effect of culture filtrate of Chaetomium globosum against soil borne pathogens 
This concluded that the culture extract of Chaetomium globosum contain some unknown chemicals which inhibit the growth of Fusarium spp. Chaetomium globosum can be used as a biocontrol agent against Fusarium spp. in future.

Tomilova et al., (2006) studied the effect of a Chaetomium fungi on the growth of phytopathogenic fungi viz., Rhizoctonia solani and Fusarium oxysporum and observed inhibitory effect of the preparation under study depended on its concentration, duration of storage, and growth characteristics of pure cultures of the phytopathogens.

\section{References}

Anonymous, 2012. Soil borne pathogens, Impact statement by agriculture research extension and education reform act, S- 1028, pp. 1-2.

Kirk P.M., Cannon P.F., Minter D.W.,
Stalpers J.A. 2008. Dictionary of fungi (10 ${ }^{\text {th }}$ ed.), pp. 131.

Liu, Z.H., Yang, Q. Hu S., Zhang, J.D. and Ma, J. 2008. Cloning and characterization of a novel chitinase gene (chi46) from Chaetomium globosum and identification of its biological activity. Appl. Microbiol. biotechnol. 80(2): 241-252.

Sibounnavong, P., Soytong, K., Divina, C.C. and Kalaw, S.P. 2005. in vitro biological activities of Emericella nidulans, a new fungal antagonist, against Fusarium oxysporum f.sp. lycopersici. J. Agric. Technol. Vol. 5(1): 75-84.

Tomilova, O.G. and Shternshis, M.V. 2006. The effect of a preparation from Chaetomium fungi on the growth of phytopathogenic fungi. App. Microbiol. Biochem. Vol. 42, Issue 1, 67-67.

\section{How to cite this article:}

Uikey, K. W., K. S. Raghuwanshi and Uikey, D. W. 2020. In Vitro Effect of Culture Filtrates of Chaetomium globosum on Growth of Soil Borne Pathogens. Int.J.Curr.Microbiol.App.Sci. 9(05): 2766-2770. doi: https://doi.org/10.20546/ijcmas.2020.905.318 